\title{
Mechanizmy współdziałania Generalnego Konserwatora Zabytków z innymi centralnymi organami administracji państwa
}

\section{Mechanisms of the cooperation of the General Conservator of Monuments with other central state administration bodies}

\section{Streszczenie}

W artykule przedstawiony został zarys organu administracji publicznej, jakim jest Generalny Konserwator Zabytków, ze zwróceniem szczególnej uwagi na wszelkie przejawy współdziałania z innymi organami w zakresie sprawowanych obowiązków. Wyczerpująco omówiono zagadnienie współdziałania w oparciu o przepisy kodeksu postępowania administracyjnego. W sprawie współdziałania w zakresie zapobiegania i zwalczania przestępczości skierowanej przeciwko zabytkom opracowane zostały trzy formy współdziałania - wymiana informacji, doskonalenie metodyki ochrony zabytków i współpraca w zakresie koordynacji działań niecierpiących zwłoki, wymagających podjęcia szybkiej reakcji.

Słowa kluczowe: współdziałanie, współkompetencja, koordynacja

\begin{abstract}
This article presents an outline of the public administration body which is the General Conservator of Monuments paying attention to all manifestations of cooperation with other bodies in the scope of their duties. The issue of cooperation based on the provisions of the Code of Administrative Procedure is thoroughly described. On cooperation in terms of preventing and combating crime directed against monuments, three forms of cooperation are presented: theexchange of information; the improvement of the methodology of monument protection; cooperation in the area of the coordination of urgent actions requiring a quick response.
\end{abstract}

Keywords: cooperation, co-competence, coordination 


\section{WPROWADZENIE}

Generalny Konserwator Zabytków stanowi organ centralny, posiadający szereg kompetencji. Swoje uprawnienia niejednokrotnie realizuje w porozumieniu z innymi podmiotami. Zgodnie z Rozporządzeniem Prezesa Rady Ministrów z dnia 31 grudnia 1998 r. w sprawie sposobu tworzenia Urzędu Generalnego Konserwatora Zabytków w 1999 r. uległa zmianie nazwa „Państwowa Służba Ochrony Zabytków” na „Służbę Ochrony Zabytków”1.

Urząd Generalnego Konserwatora Zabytków był urzędem centralnym administracji rządowej, obsługującym Generalnego Konserwatora Zabytków i działającym pod jego bezpośrednim kierownictwem, przy pomocy którego Generalny Konserwator Zabytków kierował Służbą Ochrony Zabytków². Urząd ten istniał w latach 1999-2002.

Ówczesny ustrój prezentował się następująco - Generalny Konserwator Zabytków kierował urzędem przy pomocy zastępcy Generalnego Konserwatora Zabytków, dyrektora generalnego i dyrektorów komórek organizacyjnych. W zależności od zapotrzebowania w departamentach mogły być tworzone wydziały oraz powoływane doraźne zespoły do wykonywania określonych zadań.

Następnie w latach 1999-2002 Generalny Konserwator Zabytków zyskał status ministra, działając przy pomocy wydzielonego z Ministerstwa Kultury Urzędu Generalnego Konserwatora Zabytków, który miał rangę urzędu centralnego, a który został zlikwidowany z dniem 1 lipca 2002 r. Od tego czasu Generalny Konserwator Zabytków znów stanowi część Ministerstwa Kultury i Dziedzictwa Narodowego, a jego zadania obsługiwane są przez Departament Ochrony Zabytków Ministerstwa.

\section{POJĘCIA NACZELNEGO I CENTRALNEGO ORGANU ADMINISTRACJI PUBLICZNEJ}

Dla dalszych rozważań istotne znaczenie ma rozróżnienie organów administracji państwa pod względem ich pozycji i zależności w hierarchii organizacyjnej. Pełna powiązań hierarchia składa się z licznych szczebli, na szczycie których swoje miejsce znajduje organ naczelny. Organem naczelnym nazywamy organ najwyższy w hierarchii danego pionu organizacyjnego, lecz określenie to jest używane również w innych znaczeniach (przykładowo, gdy dotyczy kwestii powołania) $)^{3}$. Możemy wyróżnić podział na organy naczelne i organy niższego szczebla, decydujący jest tutaj charakter więzi między organami. Natomiast na podstawie kryterium terytorialnego możemy wyróżnić organy centralne i organy terenowe. Kluczowe jest terytorium - kompetencja organów centralnych rozciąga się na terytorium całego państwa, podczas gdy organy terenowe są właściwie wyłącznie na określonym obszarze terytorium państwa. Każdy organ naczelny jest organem centralnym, jednak nie każdy organ centralny jest organem naczelnym. 
Na podstawie konstytucji rozróżniamy centralne konstytucyjne organy państwa oraz centralne organy państwowe. Odróżnia je nadana przez konstytucję nazwa własna, organy centralne konstytucyjne posiadają taką właśnie nazwę, drugie z nich nie mają określonej nazwy własnej w ustawie zasadniczej. Spory kompetencyjne pomiędzy centralnymi konstytucyjnymi organami państwa rozstrzyga Trybunał Konstytucyjny ${ }^{4}$.

\section{POZYCJA USTROJOWA GENERALNEGO KONSERWATORA ZABYTKÓW}

Organ ten pełni funkcję sekretarza lub podsekretarza stanu w urzędzie obsługującym ministra właściwego do spraw kultury i dziedzictwa narodowego. Jednocześnie posiada rangę wiceministra. Urząd ten jest obsadzany przez aktualnie rządzącą partię.

Zadania Generalnego Konserwatora Zabytków można zrekonstruować na podstawie ustawy o ochronie zabytków. Do jego kompetencji należy prowadzenie krajowej ewidencji zabytków. Włączenie zabytku nieruchomego do gminnej ewidencji zabytków powoduje ograniczenie wykonywania prawa własności do nieruchomości zabytkowej5.

Wojewódzki Sąd Administracyjny w Warszawie przyznał, że wpis nieruchomości do gminnej ewidencji zabytków, który zbliżony jest w skutkach do wpisu do rejestru zabytków, podlega kontroli sądowej. Ponadto podlega kontroli z punktu widzenia spełnienia przez obiekt ustawowej definicji zabytku. W gminnej ewidencji zabytków sporządzane są programy opieki nad zabytkami przez województwa, powiaty i gminy. Zawarte w niej wpisy mogą prowadzić do ograniczenia uprawnień właścicielskich - co ważne, nie może być dowolności w ich dokonywaniu'.

Zadaniem Generalnego Konserwatora jest prowadzenie krajowego wykazu zabytków skradzionych lub wywiezionych za granicę niezgodnie z prawem. Wykaz ten przyjmuje formę zbioru kart informacyjnych. W obecnym kształcie wykaz jest „narzędziem służącym Policji, Służbie Celnej i Straży Granicznej do prowadzenia poszukiwań i identyfikacji utraconych dóbr kultury"7.

Zgodnie z art. 42 ustawy o ochronie zabytków Generalny Konserwator Zabytków może podejmować pewne czynności, gdy jest to konieczne ze względu na szczególną wagę sprawy. Do kompetencji Generalnego Konserwatora Zabytków należy opracowywanie i realizacja zadań wynikających z krajowego programu ochrony zabytków i opieki nad zabytkami. Podejmuje on działania związane z wspieraniem rozwoju regionalnego i realizacją kontraktów wojewódzkich w sprawach opieki nad zabytkami. Wydaje on decyzje, postanowienia i zaświadczenia w sprawach określonych w ustawie oraz w przepisach odrębnych, organizuje i przeprowadza kontrole w zakresie przestrzegania oraz stosowania przepisów dotyczących ochrony zabytków i opieki nad zabytkami oraz sprawuje nadzór nad działalnością wojewódzkich konserwatorów zabytków. 
Kolejne dwie kompetencje zostały wprowadzone Ustawą z dnia 22 czerwca 2017 r. o zmianie ustawy o ochronie zabytków i opiece nad zabytkami oraz niektórych innych ustaw - są to koordynowanie działalności wojewódzkich konserwatorów zabytków oraz kontrolowanie działalności wojewódzkich konserwatorów zabytków (na zasadach określonych w Ustawie z dnia 15 lipca 2011 r. o kontroli w administracji rządowej) ${ }^{8}$.

\section{POJĘCIE WSPÓŁDZIAŁANIA}

Współdziałanie stanowi pewien rodzaj więzi organizacyjnej, jest zbliżone do koordynacji. Z etymologicznego punktu widzenia wyraz koordynacja pochodzi z łaciny i oznacza uzgadnianie wzajemnego działania9 ${ }^{9}$. W znaczeniu prakseologicznym koordynacja ma na celu wzajemne uzgadnianie działań podczas współpracy podmiotów w celu wypracowania wspólnego stanowiska. Mając na względzie znaczenie podmiotowe koordynacji - może mieć charakter jednopodmiotowy lub wielopodmiotowy. Może przyjmować postać samokoordynacji, taka sytuacja ma miejsce, gdy podmiot koordynujący jest jednocześnie podmiotem koordynowanym $^{10}$. Należy wyodrębnić koordynację w znaczeniu prawnym. W tym znaczeniu koordynacja może stanowić samodzielną instytucję prawną - wówczas stanowi główny przedmiot stosunku prawnego, lub może być elementem prawnego stosunku zobowiązaniowego, którego głównym przedmiotem jest inne świadczenie, natomiast koordynacja przyjmuje postać obowiązku obciążającego dłużnika lub wierzyciela ${ }^{11}$.

Współdziałanie pojawia się wyłącznie w układzie zdecentralizowanym ${ }^{12}$. Polega na harmonizowaniu działań podejmowanych przez jednostki organizacyjne, aby łatwiej osiągnąć zamierzony cel ${ }^{13}$. Należy wyodrębnić dwie kategorie form współdziałania. Pierwszą z nich są formy wprowadzane przez prawo ustrojowe - tutaj wyróżniane są liczne formuły ustawowe. Drugą kategorię stanowią formy wprowadzane przez prawo materialne - kluczowe w tym zagadnieniu są wielorakie nazwy i pojęcia. Formy mogą przyjmować postać różnych haseł chociażby „uzgodnienie”, „porozumienie”, „zgoda”, „wyrażenie stanowiska”. Należy mieć na uwadze uzasadnienie uchwały NSA w Warszawie z 15.02.1999 r.:

najluźniejszq formq współdziałania organów administracji publicznej jest współdziałanie polegajqce na zasięganiu opinii. Współdziałanie takie polega na tym, że jeden z organów jest zobowiq̨zany, przed podjęciem decyzji, do zasięgnięcia opinii w sprawie od innego organu. Organ zobowiqzany do zasięgnięcia opinii nie jest prawnie zwiqzany stanowiskiem organu opiniujq̨cego. Współdziałanie, którego istota jest wyrażenie opinii, zbliżone jest do konsultacji czy też doradztwa ${ }^{14}$.

Wówczas możliwe jest stopniowanie, klasyfikowanie powyżej przywołanych form współdziałania. Bez względu na użytą nazwę istotna jest konsekwencja w jej używaniu. Fundamentalnym jest art. 106 par. 1 k.p.a.: „Jeżeli przepis prawa uzależnia wydanie decyzji od zajęcia stanowiska przez inny organ (wyrażenia opinii lub zgody albo wyrażenia stanowiska 
w innej formie), decyzję wydaje się po zajęciu stanowiska przez ten organ”. Nie można powiedzieć, że artykuł ten stanowi podstawę prawną współdziałania, ponieważ taką podstawą są przepisy szczególne, uzależniające wydanie decyzji od zajęcia stanowiska przez inny organ. Przepis 106 k.p.a. zawiera jedynie zasady i tryb współdziałania, jednoznacznie dotyczy on wyłącznie kwestii proceduralnych współdziałania ${ }^{15}$.

Organ współdziałający ma obowiązek określić swoje stanowisko niezwłocznie, nie może to nastąpić jednak w terminie dłuższym niż dwa tygodnie od doręczenia żądania, chyba że ustawa stanowi inaczej. Samo zajęcie stanowiska następuje w formie postanowienia, które jest zaskarżalne zażaleniem. Zasadnicze jest rozróżnienie rodzajów współdziałania poprzez wzięcie pod uwagę mocy wiążącej stanowiska organu współdziałającego ${ }^{16}$. Można wyróżnić przypadki, w których stanowisko organu nie jest wiążące, takie, gdzie jest wiążące, oraz gdy rozważenie stanowiska jest obowiązkowe. Obowiązek współdziałania jest spotykany najczęściej w sprawach dotyczących więcej niż jednej strony, ma tutaj znaczenie wpływ rozstrzygnięcia na sytuację osób trzecich. Obowiązek ten jest wyrażany zazwyczaj następującymi sformułowaniami: „w uzgodnieniu”, „po porozumieniu”, „za zgodą”, „po zajęciu stanowiska”, „po zasięgnięciu opinii”. Według poglądów w doktrynie można wartościować powyższe sformułowania co do ich mocy. Najbardziej wiążące jest wyrażenie „za zgodą". Kolejno nieco mniej stanowczymi są wyrażenia „w uzgodnieniu”, „w porozumieniu” czy „po uzgodnieniu”. Znikomą moc ma natomiast określenie „po zasięgnięciu opinii”"17.

Niewątpliwy wpływ współdziałania organów na dobro postępowania został wyrażony w art. 7b dodanym do kodeksu postępowania administracyjnego nowelą kwietniową z 2017 r. Treść tego przepisu brzmi: „W toku postępowania organy administracji publicznej współdziałają ze sobą w zakresie niezbędnym do dokładnego wyjaśnienia stanu faktycznego i prawnego sprawy, mając na względzie interes społeczny i słuszny interes obywateli oraz sprawność postępowania, przy pomocy środków adekwatnych do charakteru, okoliczności i stopnia złożoności sprawy". Przepis ten najprawdopodobniej znajduje swoje zakorzenienie w regulacji fińskiego kodeksu postępowania administracyjnego z $2003 \mathrm{r}^{18}$ Bez wątpienia należy się do niego odnieść i stanowi znaczne ułatwienie interpretacyjne podczas wykładni i stosowania przepisów - wspomnianego wcześniej art. 106, ale także art. 52 oraz 106a k.p.a. ${ }^{19}$

Przepisem 106a k.p.a. została wprowadzona instytucja posiedzenia w trybie współdziałania. Cel wprowadzenia tej instytucji możemy znaleźć w uzasadnieniu projektu ustawy jest nim

usprawnienie postępowań, w których organ prowadzqcy postępowanie wydaje rozstrzygnięcie po uzyskaniu stanowiska innego organu. Brak stanowiska takiego organu w ustawowym czasie, a przez to brak możliwości wydania decyzji przez organ załatwiający sprawę, może doprowadzić do sytuacji, w której oba te organy będq narażone na zarzut przewlekłego prowadzenia postępowania. Posiedzenie w trybie współdziałania poprzez wymianę argumentów i wyłożenie racji wszystkich uczestników postępowania pozwoliłoby w szerszym niż obecnie stopniu realizować zasady ogólne k.p.a., w tym zasadę zaufania do organów państwa ${ }^{20}$. 
W przypadku braku zasięgnięcia stanowiska organu współdziałającego - brak ten stanowi kwalifikowaną wadę postępowania. Jest to podstawa do wznowienia postępowania zakończonego decyzją ostateczną.

\section{WSPÓŁDZIAŁANIE GENERALNEGO KONSERWATORA ZABYTKÓW Z KOMENDANTEM GŁÓWNYM POLICJI}

Koniecznym jest, aby w zakresie swoich obowiązków GKZ działał wspólnie z innymi centralnymi organami administracji. Komendant Główny Policji podlega Ministrowi Spraw Wewnętrznych. Jest on organem centralnym, natomiast nie jest organem naczelnym.

Generalny Konserwator wraz z Komendantem Głównym Policji współdziała w zakresie zapobiegania i zwalczania przestępczości skierowanej przeciwko zabytkom. Zagadnienie to najpełniej można omówić, odwołując się do treści porozumienia zawartego pomiędzy dwoma wspomnianymi wcześniej organami ${ }^{21}$. Porozumienie obejmuje dwa typy zadań pierwszą kategorią są „zadania organów ochrony zabytków i podległych im instytucji kultury wyspecjalizowanych w opiece nad zabytkami, mające na celu przeciwdziałanie przestępczości skierowanej przeciwko zabytkom, których wspomaganie jest możliwe w zakresie działania Policji”, drugą kategorią są „zadania Policji mające na celu zapobieganie popełnianiu przestępstw i wykroczeń oraz zjawiskom kryminogennym oraz ściganie czynów karalnych, których wspomaganie jest możliwe w zakresie działania organów ochrony zabytków i podległych im instytucji kultury wyspecjalizowanych w opiece nad zabytkami"22.

Współdziałanie jest realizowane w trzech formach. Możemy wyróżnić wymianę informacji, doskonalenie metodyki ochrony zabytków, a także współpracę w zakresie koordynacji działań niecierpiących zwłoki, wymagających podjęcia szybkiej reakcji, które dotyczą kwestii zapobiegania utracie i odzyskania utraconych zabytków. Doskonalenie metodyki ochrony zabytków może polegać na wymianie opracowań koncepcyjnych i materiałów szkoleniowych, które dotyczą opieki nad zabytkami oraz zapobiegania i zwalczania przestępczości skierowanej przeciwko zabytkom. Może też bazować na organizowaniu wspólnego szkolenia dla policjantów oraz pracowników urzędów ochrony zabytków.

Natomiast wspomniana koordynacja działań, może przyjmować postać konsultacji poprzedzających przedsięwzięcia wykonawcze czy bieżącą wymianę informacji o przebiegu przedsięwzięć wykonawczych. W ramach koordynacji działań niecierpiących zwłoki można powoływać wspólne zespoły koordynacyjne do planowania przebiegu współdziałania, bezpośredniego kierowania lub nadzoru nad czynnościami prowadzonymi w ramach współdziałania lub do analizy i oceny rezultatów tych czynności. Zespoły te mogą być powoływane przez strony lub przez ich uprawnionych przedstawicieli. Kierownik zespołu wyznaczany jest przez stronę wnioskującą o powołanie zespołu. Koordynacja może przejawiać się 
podejmowaniem przez organy ochrony zabytków czynności kontrolnych na wniosek uprawnionych przedstawicieli policji oraz udzielaniem przez policję wsparcia w zakresie ochrony przemieszczania (transportu) zabytków.

\section{WNIOSKI KOŃCOWE}

W obecnym kształcie prawnym GKZ posiada szereg wielopłaszczyznowych kompetencji, przeplatających się ze wspomnianymi wyżej organami. Działania podejmowane przez Generalnego Konserwatora Zabytków muszą wyrażać się zarówno we współpracy z wojewódzkimi konserwatorami zabytków, których lokalne starania mają mieć wyraz w czuwaniu nad przestrzeganiem przepisów przez właścicieli i zarządców nieruchomości. Jednak niezbędne są wprowadzane kolejne zmiany - chociażby w zakresie poszerzania wiedzy i świadomości obywateli w ramach organizowanych działań edukacyjnych, wszelkiego rodzaju szkoleń dotyczących ochrony i przeciwdziałania przestępczości przeciwko zabytkom. Do zapewnienia skutecznej ochrony konieczne jest stworzenie mechanizmów, właściwych rozwiązań na poziomie regionalnym, samorządowym. Dlatego też nieodzownym jest uregulowanie metod radzenia sobie z pojawiającymi się wyzwaniami w nowym Krajowym Programie Ochrony Zabytków. Mają w nim zostać określone cele i kierunki działań, lecz także warunki i sposób finansowania planowanych działań oraz harmonogram ich realizacji. Głównym celem wspomnianego programu będzie wzmocnienie systemu ochrony na poziomie lokalnym oraz centralnym.

\section{PRZYPISY}

1 Rozporządzenie Prezesa Rady Ministrów z dnia 31 grudnia 1998 r. w sprawie sposobu tworzenia Urzędu Generalnego Konserwatora Zabytków, Dz.U.1998.166.1206.

2 Rozporządzenie Prezesa Rady Ministrów z dnia 31 grudnia 1998 r. w sprawie nadania statutu Urzędowi Generalnego Konserwatora Zabytków, Dz.U.1998.166.1207.

3 J. Zimmermann, Prawo administracyjne, Wolters Kluwer, Warszawa 2014, s. 147.

4 Art. 189 Konstytucji RP.

5 A. Ginter, A. Michalak, Komentarz do art. 22, [w:] A. Ginter, A. Michalak, Ustawa o ochronie zabytków i opiece nad zabytkami. Komentarz, Wolters Kluwer, Warszawa 2016.

6 Wojewódzki Sąd Administracyjny w Warszawie, wyrok z dnia 3 lipca 2013 r., VII SA/Wa 2652/12, LEX nr 1352709.

7 A. Ginter, A. Michalak, op. cit.

8 P. Antoniak, M. Cherka, F. Elżanowski, A. Wąsowski, Ustawa o ochronie zabytków i opiece nad zabytkami. Komentarz, red. M. Cherka, Wolters Kluwer, Warszawa 2010, s. 196. 
9 Słownik wyrazów obcych, red. J. Tokarski, PWN, Warszawa 1974, s. 390.

10 B. Wróblewska-Perucka, Przygotowanie inwestycji budowlanej do realizacji, Dom Wydawniczy „Ostoja”, Kraków 1998, s. 45.

11 I. Weiss, Prawne znaczenie pojęcia koordynacji, Krakowskie Studia Prawnicze, XII/1979, s. 25.

12 Postępowanie administracyjne, red. nauk. T. Woś, A. Golęba, M. Kamiński, T. Kiełkowski, H. Knysiak-Sudyka, Wolters Kluwer, Warszawa 2017, s. 183.

13 Ibidem.

14 Uchwała (5) NSA w Warszawie z 15.02.1999 r., OPK 14/98, ONSA 1999/3, poz. 80.

15 J. Borkowski, Komentarz do art. 106, [w:] B. Adamiak, J. Borkowski, Kodeks postępowania administracyjnego. Komentarz, CH Beck, Warszawa 2003, s. 467.

16 J. Zimmermann, op. cit., s. 185.

17 J. Borkowski, Współdziałanie organów administracji państwowej przy wydawaniu indywidualnych decyzji administracyjnych, [w:] Zeszyty Naukowe Uniwersytetu Łódzkiego. Nauki Humanistyczno-Społeczne, z. 31, Łódź 1963, s. 78-83.

18 Administrative Procedure Act.

19 Postępowanie administracyjne, op. cit., s. 135.

20 Uzasadnienie projektu ustawy z 7.04.2017 r. o zmianie ustawy - Kodeks postępowania administracyjnego oraz niektórych innych ustaw (VIII kadencja, druk sejm. nr 1183).

${ }^{21}$ Dz.Urz.KGP.2005.6.29.

22 Porozumienie $\S 1$ ust. 1 , pkt 1 i 2.

\section{BIBLIOGRAFIA}

Wydawnictwa książkowe:

Adamiak B., Borkowski J., Kodeks postępowania administracyjnego. Komentarz, CH Beck, Warszawa 2003.

Antoniak P., Cherka M., Elżanowski F., Wąsowski A., Ustawa o ochronie zabytków i opiece nad zabytkami. Komentarz, red. M. Cherka, Wolters Kluwer, Warszawa 2010.

Borkowski J., Współdziałanie organów administracji państwowej przy wydawaniu indywidualnych decyzji administracyjnych, [w:] Zeszyty Naukowe Uniwersytetu Łódzkiego. Nauki Humanistyczno-Społeczne, z. 31, Łódź 1963, 78-83.

Ginter A., Michalak A., Ustawa o ochronie zabytków i opiece nad zabytkami. Komentarz, Wolters Kluwer, Warszawa 2016.

Postępowanie administracyjne, red. nauk. T. Woś, A. Golęba, M. Kamiński, T. Kiełkowski, H. Knysiak-Sudyka, Wolters Kluwer, Warszawa 2017.

Słownik wyrazów obcych, red. J. Tokarski, PWN, Warszawa 1974.

Weiss I., Prawne znaczenie pojęcia koordynacji, Krakowskie Studia Prawnicze, XII/1979. 
Wróblewska-Perucka B., Przygotowanie inwestycji budowlanej do realizacji, Dom Wydawniczy „Ostoja”, Kraków 1998.

Zimmermann J., Prawo administracyjne, Wolters Kluwer, Warszawa 2014.

Akty prawne:

Rozporządzenie Prezesa Rady Ministrów z dnia 31 grudnia 1998 r. w sprawie sposobu tworzenia Urzędu Generalnego Konserwatora Zabytków, Dz.U.1998.166.1206.

Rozporządzenie Prezesa Rady Ministrów z dnia 31 grudnia 1998 r. w sprawie nadania statutu Urzędowi Generalnego Konserwatora Zabytków, Dz.U.1998.166.1207.

Porozumienie Komendanta Głównego Policji z Generalnym Konserwatorem Zabytków,

Dz.Urz. KGP.2005.6.29.

Wojewódzki Sąd Administracyjny w Warszawie, wyrok z dnia 3 lipca 2013 r., VII SA/Wa 2652/12, LEX nr 1352709.

Uchwała (5) NSA w Warszawie z 15.02.1999 r., OPK 14/98, ONSA 1999/3, poz. 80.

Uzasadnienie projektu ustawy z 7.04.2017 r. o zmianie ustawy - Kodeks postępowania administracyjnego oraz niektórych innych ustaw (VIII kadencja, druk sejm. nr 1183).

Strony internetowe:

https://skradzionezabytki.pl/i/\#/history (dostęp: 02.03.2019).

https://bip.kprm.gov.pl/kpr/form/r750131964,Projekt-uchwaly-Rady-Ministrow-w-sprawieustanowienia-Krajowego-programu-ochrony.html07 (dostęp: 02.03.2019). 